\title{
The power of materialism among young adults: exploring the effects of values on impulsiveness and responsible financial behavior
}

\author{
Andrea Lučić', Marija Uzelac and Andrea Previšić
}

\author{
Andrea Lučić and \\ Marija Uzelac are both \\ based at the Department of \\ Marketing, Faculty of \\ Economics and Business, \\ University of Zagreb, \\ Croatia. \\ Andrea Previšić is based at \\ the Department of \\ Marketing, Pipi Beverages, \\ Split, Croatia.
}

\footnotetext{
Received 25 September 2020 Revised 31 December 2020 Accepted 8 February 2021

(C) Andrea Lučić, Marija Uzelac and Andrea Previšić. Published by Emerald Publishing Limited.

This article is published under the Creative Commons Attribution (CC BY 4.0) licence. Anyone may reproduce, distribute, translate and create derivative works of this article (for both commercial and non-commercial purposes), subject to full attribution to the original publication and authors. The full terms of this licence may be seen at http:// creativecommons.org/ licences/by/4.0/legalcode

This paper is based on research undertaken in the frame of the Project of the Croatian Science Foundation UIP-2019-04-3580 "EfFICAcY Empowering financial capability of young consumers through education and behavioural intervention.
}

\begin{abstract}
Purpose - The purpose of this paper is to investigate the effects of values of materialism on cognitive and affective impulsiveness and responsible financial behavior among young adults.

Design/methodology/approach - A large-scale study $(\mathrm{n}=483)$ was conducted on a sample of young adults 18 to 25 years of age in Croatia.

Findings - The research found that materialism has no direct effect on responsible financial behaviour (RFB), however, cognitive impulsiveness fully mediates the relationship of all three there three elements of materialism, centrality, success and happiness and RFB. Affective impulsiveness has no effect on the relationship. Furthermore, only materialism as centrality strongly and positively influences cognitive and affective impulsiveness.

Practical implications - Presented conclusions could be used by policymakers as guidelines for developing educational plans and curriculum to build financial capability and consumer protection among young adults and could be helpful for brand management activities targeting young people purchase decisions.

Originality/value - This paper's ultimate purpose is to uncover the mechanism and the power of materialism on impulsiveness and responsible financial behavior. The paper's originality is established by the focus on the investigation of materialism as an antecedent factor of impulsiveness and by questioning the nature of the relationship between materialism and responsible financial behavior through the mediating effect of impulsiveness.
\end{abstract}

Keywords Young adults, Materialism, Impulsiveness, Financial behavior, Responsible financial behavior

Paper type Research paper

\section{Introduction}

There has been a growing interest in the investigation of responsible financial behavior of young adults (Pinto et al., 2000; Watson, 2003; Norvilitis et al., 2006; Yang et al., 2008; Tang et al., 2015; Bamforth et al., 2018; Bapat, 2020). Efficient and well-structured financial decisions, hence responsible financial behavior, is crucial for young people's prosperity in personal and professional life (Sachitra et al., 2019), as well as in the advance of general well-being (Helm, et al., 2019). Therefore, it is necessary to investigate young adults' financial behavior to better understand and predict their financial behavior but also to encourage responsible and avoid irresponsible financial behaviors.

Materialism has been identified as "the importance a consumer attaches to worldly possessions" (Belk, 1984, p. 291) or as a system of personal values (Richins and Dawson, 
1992), which involves placing material possessions at the center of life. Understanding the outcomes related to this tendency have become more important as a wealth of research studies suggested its negative relation to consumer spending tendencies and consumer well-being (Ahuvia and Wong, 2002; Sirgy, 1998; Burroughs and Rindfleisch, 2002; Watson, 2003) especially among young adults.

Even though there has been an array of studies on the relationship between materialistic values and consumption (Podoshen and Andrzejewski, 2012; Lysonski and Durvasula, 2013; Ahuvia and Wong, 2002; Sirgy, 1998; Pandelaere, 2016) and related to individuals financial management (Watson, 2003; Richins and Dawson, 1992; Arndt et al., 2004) the role of materialism as an antecedent factor that influences cognitive and affective impulsiveness is under-researched and not well-understood. Various studies have indicated that because of the increased need for social acceptance materialism among the young has a great impact on consumption behavior (Yang et al., 2008; Demirbag et al., 2010; Xu, 2008), indicating the importance of further examination of the outcomes of materialism on financial behavior.

Though the large-scale quantitative study this study contributes to the published literature:

- As it provides an investigation of the influence of materialistic values (centrality, success and happiness) of young adults on the consumption behavior (that yet, has not been studied).

- As it is focused on the investigation of materialism (as centrality, success and happiness) as an antecedent factor of affective and cognitive impulsiveness.

- As it questions the nature of the relationship between materialism (as centrality, success and happiness) and responsible financial behavior through the mediating effect of impulsiveness.

Therefore, this paper's ultimate purpose is to uncover the mechanism and the power of materialism on the impulsiveness and responsible financial behavior that is significant for both researchers and public policymakers. As empirical evidence on the nature of the relationships in questions is either under-researched or inconclusive. The revelation of the nature of the relationship will help in building strong consumer protection policies for young adults and national strategies for building their financial capability.

The paper is structured as follows: first, we define materialism, responsible financial behavior of young adults and compulsiveness. Subsequently, we present hypothesis development backed up by the current state of relevant published literature, as well as methodology and the results of structural equation modeling. Finally, we offer a discussion followed by a conclusion and research limitations.

\section{Theoretical foundation}

\subsection{Materialism}

The term materialism mostly refers to how paramount acquisition of material goods is to an individual, with the implication that these material possessions will lead to their happiness and life satisfaction (Podoshen and Andrzejewski, 2012; Richins and Dawson, 1992). Thus, this trait has always been strongly identified with consumption (Lee and Ahn, 2016).

Consumer research studies (Ryan and Dziurawiec, 2001; Christopher et al., 2004; Watson, 2015) examined the concept of materialism mostly through conceptualizations of two prevailing theoretical perspectives developed by Belk (1984) and Richins and Dawson (1992). While Belk's (1984) conceptualization focuses on materialism as a collection of three personality traits; envy, possessiveness and no generosity (Ahuvia and Wong, 2002), Richins and Dawson (1992) comprise three main themes that construct materialism. Centrality addresses the focus of materialists on the acquisition of goods and services. 
Happiness concerns the premise that those acquisitions are essential to their satisfaction, and success measures how one judges themselves and others in terms of quantity and quality of accumulated goods (Tang et al., 2014). The main difference between these two scales is that Belk's (1984) primarily relies on emotional reactions as opposed to Richins and Dawson (1992), who approach it through the set of cognitive beliefs. In other words, building off Rokeach (1973) definition of values as enduring beliefs that guides actions and judgments (Richins and Dawson, 1992), materialism can be viewed as a value that influences people's choices and conduct, hence the quantity and type of purchased goods and services (Richins and Dawson, 1992). Thus, that is the reasoning why Richins and Dawson (1992) theoretical reasoning was set as the founding block for this paper.

Moreover, as self-worth is often gained through social acceptance, subsequently materialists value success through material possessions, to manage and maintain wanted impressions they give off to others, materialists' propensity to spend leads to their more favorable attitudes toward spending and borrowing, therefore effecting their individual financial management level (Watson, 2003; Arndt et al., 2004).

\subsection{Responsible financial behavior of young adults}

Responsible financial behavior is associated with one's ability to make financial decisions that are only to their best interest for overall well-being, including cash management, savings, credit use and consumption management (Xiao and Dew, 2011). It also implies responsible everyday purchase decision-making that maximizes consumption benefit. It can also be understood within the definition of utilitarian behavior that entails primarily rational consumer decisions (Rucker and Galinsky, 2009). It comprises a diverse set of actions related to personal finance, namely, spending self-control, spending selfpredictions, seeking consumer information, taking part in consumer education, rational decision-making and solvency (Barbić et al., 2019). To be built, one needs to have relevant financial knowledge, skills and opportunities (Johnson and Sherraden, 2007).

For young adults to achieve responsible financial behavior and make an effective financial decision, it is necessary to develop an efficient set of money management skills at an earlier age (Bamforth et al., 2018). Money management leads to better controlling and managing personal finances (Taylor, 2011) and makes contributions to financial satisfaction and financial well-being (Xiao, 2008). In other words, it is crucial for young people to adapt money management skills at an earlier age to act responsibly in the context of finance in the future and make an efficient and prosperous financial decision.

Even though some authors regard the impact of materialism on the economy as positive due to higher spending (Kasser et al., 2007; Richins and Rudmin, 1994), a tendency toward materialism among young adults can become a significant problem that in terms of over indebtedness. They often resort to indebtedness to satisfy consumption desires (Bernthal et al., 2005). At the same time, they are very vulnerable borrowers, mostly because of their ignorance and belief that they will be able to pay off the debt in the future. Hauss et al. (2019). Therefore, considering the great importance of responsible financial behavior for economic well-being (Barbić et al., 2019) it is crucial to investigate and encourage habits and skills young adults should develop to act responsibly while making financial decisions.

\subsection{Cognitive and affective impulsiveness}

Impulsive buying tendency is described as desire-driven impulse to buy, where a consumer is motivated by immediate reward, more so than the long-term consequence. Due to this, impulsive buying is often related to a lack of planning and absence of deliberation (de Meza et al., 2008; Rook and Fisher, 1995). While making a purchase, the consumer triggers affective and cognitive aspect of the decision-making process (de Meza et al., 2008). Affective is prompt by emotions such as fear, excitement and satisfaction while the 
cognitive aspect is related to deliberation and planning, which is the lack of it Verplanken and Herabadi (2001). While making purchase decisions, peoples are not always rational. So, irrational and emotion-driven purchase behavior is defined as impulsive buying. Therefore, this kind of irresponsible purchase behavior consequently leads to irresponsible financial behavior. According to Jelihovschi et al. (2018) impulsiveness, also, leads to inefficient financial decisions and, consequently, to irresponsible financial behavior. On the other hand, rational decisions, planning and self-control during the purchase are connected to responsible financial behavior (Barbić et al., 2019).

\section{Hypothesis development and conceptual framework}

Correlation between responsible financial behavior, materialism and impulsiveness can be demonstrated by Maslow's hierarchical theory of human needs (Chen, 2016). Maslow (1954) defined human needs through the pyramidal structure where the basic level represents elementary human needs such as water and food, proceeding to the physical social and personal needs. To achieve higher layers or to develop responsible financial behavior, a person needs to start from the basic layers and move progressively to the top (Chen, 2016). The effect of materialism on responsible financial behavior, therefore lies in the recognition that persons who are prone to materialism are most likely to immediately shift to self-gratification, skipping the previous layers. Therefore, these persons are also prone to make ineffective financial decisions and vulnerable to irresponsible financial behavior (Barbić et al., 2019). Building on that reasoning, a wealth of research linked it to a negative outcome such as compulsive buying (Burroughs and Rindfleisch, 2002; Nga et al., 2011; Phau and Woo, 2008), as well as lower levels of well- being (Ahuvia and Wong, 2002), tendency to indebtedness (Watson, 2003; Garðarsdottir and Dittmar, 2012; de Matos et al., 2019) and usage of money for increasing of personal value (Christopher et al., 2004).

At the same time, there has been a lack of consensus within the body of published research on the influence of the materialism paradigm on consumer behavior, especially in terms of financial conduct that can be observed in Table 1. Richins and Dawson (1992) suggested that to those high in proneness to materialism, financial security is of great importance, therefore it can positively affect the individuals' allocation of resources. Cakarnis and D'Alessandro (2015) found that materialism increases consumer motivation for greater knowledge of financial products when needed to allocate their scarce financial resources. Furthermore, Kasser et al. (2007) and Richins and Rudmin (1994) argued that materialism has a positive impact on the economy because of materialists' need for higher living standards that encourage people to work more, thus have higher incomes and greater consumption (Garðarsdottir and Dittmar, 2012). Nevertheless, it is an overall consensus that materialism does increase consumption. Lee and Ahn's (2016) research support this premise as their data showed that those high in materialistic values have lower control over their consumption and vice versa.

Such conflicting results, we believe, are to be found mostly because of two things, namely, first is the fact that materialism consists of three sets of values that underline materialistic behavior that might have different effects, and therefore, should be examined as separate variables; and second because of the impulsiveness that mediates the relationship between the materialism and responsible financial behavior:

H1. The relationship between materialism and responsible financial behavior is mediated by cognitive impulsiveness.

H2. The relationship between elements of materialism and responsible financial behavior is mediated by affective impulsiveness.

Understanding the set of values that underline materialistic behavior is vital for understanding their effect on impulsive consumer behavior. Therefore, it is important to further examine the outcome of those values on the affective and cognitive aspects of 


\begin{tabular}{llll} 
Antecedent & Outcome & Concept & Reference \\
\hline Materialism & Positive & $\begin{array}{l}\text { For those high in materialism financial } \\
\text { security is of great importance } \\
\text { Materialism increases motivation for greater } \\
\text { knowledge of financial products }\end{array}$ & Richins and Dawson (1992) \\
& & $\begin{array}{l}\text { Materialism has a positive impact on the } \\
\text { economy because of higher earnings and }\end{array}$ & Kasser et al. (2007), Richins and Rudmin \\
& & (1994)
\end{tabular}

impulsiveness. To comprehend those effects, we have sorted previously conducted depending on what values they have examined available in Table 2.

Centrality addresses the focus of materialists on the acquisition of goods and services. As the role of objects in people's definition of themselves is of vital importance, people tend to invest more in those goods that will express and communicate their identity than in those that are purely functional (Dittmar and Bond, 2010; Csikszentmihalyi and Rochberg-Halton, 1981). The awareness of one's own existence and assumption of control of that existence through acquisition makes individuals believe that they reflect the things that they own (Csikszentmihalyi and Rochberg-Halton, 1981), consequently leading them to purchase to exist. Considering the cognitive aspect, public opinion and self-consciousness, influenced by materialism, affect purchase decisions (Richins, 1994; Xu, 2008). In the context of affective impulsiveness, materialism, through the purchasing of specific goods, allows a person to experience desired emotions or to acquire wanted personality traits (Chatterjee and Farkas, 1992; Dittmar, 2000).

Success measures how one judges themselves and others in terms of quantity and quality of accumulated goods (Richins, 1994). For those who endorse materialistic values, acquiring new material goods presents communication of social status and desired image (Dittmar and Bond, 2010). Therefore, while making a purchase decision one is more likely to deliberate on product attributes and characteristics to make sure it reflects their ideal self-image. This rationalizing and the perception of the utilitarian value of a product is correlated with rational and cognitive purchase (Santini et al., 2019). Therefore, cognitive impulsiveness involves making purchasing decisions considering the pursuit of success (Chen, 2016; Cakarnis and D'Alessandro, 2015; Demirbag et al., 2010). Regarding the affective aspect, success can be viewed through so-called "status consumption" defined as the motivational process by which individuals strive to improve their social standing through conspicuous consumption (Eastman et al., 1999, p. 42) and it is triggered by a desire for status.

Happiness concerns the premise that specific acquisitions are essential to a person's satisfaction. The pursuit of happiness through acquisition mainly positively correlates with income level (Kasser et al., 1995; Roberts and Clement, 2007). Meaning that the lower the income, the greater the possibility of one believes that material possession would lead to greater happiness. However, pursuit of happiness through acquisition mostly leads to 
Table 2 Effect of values on two aspects of impulsiveness

Materialistic value as antecedent factor

Impulsiveness Concept

Reference

\begin{tabular}{|c|c|c|c|}
\hline \multirow[t]{5}{*}{ Centrality } & Cognitive & & \\
\hline & & $\begin{array}{l}\text { The level of cognition materialist give to public opinion, increase their } \\
\text { deliberation before purchasing a product }\end{array}$ & Richins (1994) \\
\hline & & $\begin{array}{l}\text { The influence of public self-consciousness on compulsive buying } \\
\text { tendency was mediated by materialism }\end{array}$ & Xu (2008) \\
\hline & Affective & $\begin{array}{l}\text { Materialists use material goods as compensation for some personal } \\
\text { weaknesses such as a low self-esteem }\end{array}$ & $\begin{array}{l}\text { Chatterjee and Farkas } \\
\text { (1992) }\end{array}$ \\
\hline & & $\begin{array}{l}\text { It emphasizes understanding the disorder as a desperate search for } \\
\text { self in people whose identity is not securely established }\end{array}$ & Dittmar (2000) \\
\hline \multirow[t]{5}{*}{ Success } & Cognitive & & \\
\hline & & $\begin{array}{l}\text { When an individual is power-motivated, in the presence of a threat } \\
\text { that can remove that power, those individuals are prone to make } \\
\text { non-risky financial decisions }\end{array}$ & Chen (2016) \\
\hline & & Materialism motivates a consumer to make better financial decisions & $\begin{array}{l}\text { Cakarnis and D'Alessandro } \\
\text { (2015) }\end{array}$ \\
\hline & & $\begin{array}{l}\text { The country image plays a significant role among materialists when it } \\
\text { comes to valuing more expensive products the those less expensive }\end{array}$ & Demirbag et al. (2010), \\
\hline & Affective & $\begin{array}{l}\text { Individuals who especially valued financial success are likely to have } \\
\text { come from more socioeconomically disadvantaged through } \\
\text { materialism satisfied need for security and connectedness to others }\end{array}$ & Kasser et al. (1995) \\
\hline \multirow[t]{4}{*}{ Happiness } & Cognitive & & \\
\hline & & Positive financial goals contribute to happiness & Stone et al. (2008) \\
\hline & Affective & $\begin{array}{l}\text { Materialism and its happiness dimension are negatively related to all } \\
\text { eight measures of } Q O L\end{array}$ & $\begin{array}{l}\text { Roberts and Clement } \\
\text { (2007) }\end{array}$ \\
\hline & & $\begin{array}{l}\text { Teens may focus more on external satisfaction, as intrinsic sources } \\
\text { of worth were not supported by disadvantaged communities }\end{array}$ & Kasser et al. (1995) \\
\hline
\end{tabular}

discontent with life satisfaction in general (Ryan and Dziurawiec, 2001), as materialists are prone to set their standards of living unrealistically high (Sirgy, 1998). Even though it has an obvious connection to affective impulsiveness, this value is interpreted as a cognitivejudgmental process (Diener et al., 1985):

H3. Materialism positively influences cognitive impulsiveness.

H3a. Materialism as success positively influences cognitive impulsiveness.

H3b. Materialism as centrality positively influences cognitive impulsiveness.

H3c. Materialism as happiness positively influences cognitive impulsiveness.

H4. Materialism positively influences affective impulsiveness.

H4a. Materialism as success positively influences affective impulsiveness.

H4b. Materialism as centrality positively influences affective impulsiveness.

H4c. Materialism as happiness positively influences affective impulsiveness.

Building on the presented theoretical foundations, we propose the following model (Figure 1).

\section{Methodology}

\subsection{Measures}

The questionnaire consisted of four parts, namely, questions related to two types of impulsiveness, items related to materialism the questions regarding the responsible financial behavior and the demographic data of the respondents. All interval items were 


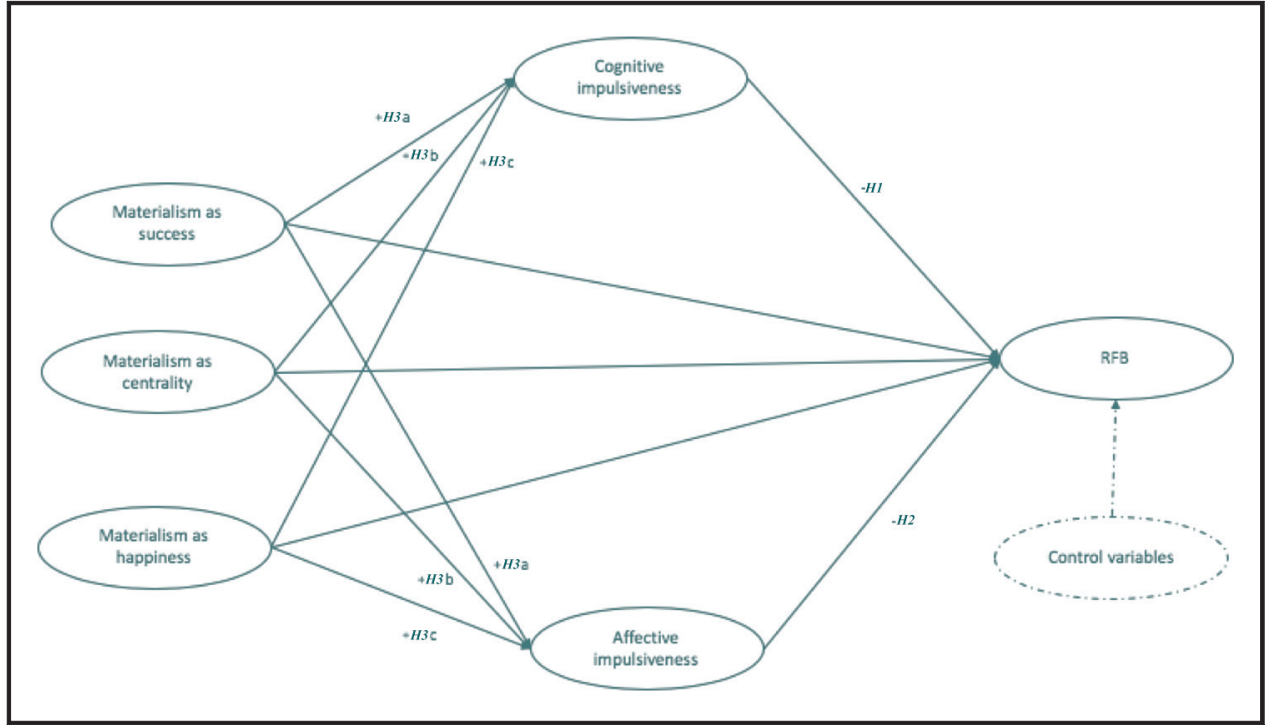

measured using a seven-point Likert scale in line with methodological recommendations (McKelvie, 1978).

Impulsiveness was taken over from the scale established by Verplanken and Herabadi (2001), who propose a 20-item scale, where half of the items measure cognitive and half affective impulsiveness. Cognitive impulsiveness includes aspects such as lack of planning and deliberation where affective aspects comprise feelings of pleasure, excitement, compulsion and lack of control. Furthermore, the materialism scale was developed by Richins and Dawson (1992) and measures materialism through three subcategories: materialism as possession-defined success; as acquisition centrality and as acquisition as the pursuit of happiness. Success is measured by seven items, centrality with seven items and happiness with five. Finally, responsible financial behavior is measured by the formative scale developed by Barbić et al. (2019) that consists of six items.

The last part consisted of demographical measures. The demographical measures also included the investigation also included three control variables, namely, age, sex and mother's education coherent with the published literature.

\subsection{Data collection procedure}

The population of the research were students of economics and business, to test the model on the biased population in terms of knowledge of personal finance and consumer behavior. We assume that individuals who are more exposed to information regarding responsible financial behavior have tendencies to behave that way, thus are positively biased ensuring the relevance of the investigated relationship. Such an approach is found in similar research (Xiao et al., 2011; Robb and Sharpe, 2009) and is adequate for investigating financial behavior among young adults. The population of students in economics and business in Croatia is around 30,000, whereas the majority of the studies in Zagreb regardless of where they come from, therefore, the sample was focused on only one location. In Zagreb, there was only one university offering that type of program (other schools and colleges offer professional degrees and have a negligible small share of students) where the research took place. 
Prior to the official data collection, to ensure clarity, avoid ambiguity and investigate the required time the questionnaire was pretested in the pilot study on the sample of 50 firstyear business students.

The data collection procedure included personal questionnaire collection on the sample of young adults, students of Economic and Business in Zagreb. The lecturing groups of students that were given the questionnaire were randomly chosen within the pool of groups for each year of the studies, hence the age and studies level was taken into consideration. The students were asked to fill in the questionnaire individually in the classroom setting with the professor and the researcher present during the entire procedure.

15 of the students in total that were presented the research refused to fill in the questionnaire, and the data collection resulted in 510 questionnaires, where 483 were complete and entered the final analysis of the results.

\subsection{Sample composition}

The sample consists of 483 individuals out of which $62.99 \%$ were women and $37.01 \%$ were men. The sample consists predominantly of $19(17.18 \%), 20(36.02 \%), 21(16.15 \%)$ and 22 (11.18\%) year olds from Zagreb (43\%) but also from all other parts of Croatia. Most of the young people in the sample come from a household that has three or four members $(56.55 \%)$ and most mothers and fathers have completed secondary level of schooling. In terms of the income; 16\% households' income is from $6,401-11,400 \mathrm{kn}, 19 \%$ $11,401-16,400 \mathrm{kn}, 13 \%$ 16,401-21,400 kn, 3\% 21,401-26,400 kn, 4\% 26,401-31,400 kn and the rest is either above or below. An overview of the sample composition is available in Table 3.

Most of the households that young people come from are loan users (50.31\%), the vast majority of them live in homes that are owned by their household members $(94.20 \%)$ that have acquired their real estate either from credit (38.10\%), cash $(27.54 \%)$ or by heritage (29.19\%).

The sample is predominantly financed by allowance as given in Table 4. Respondents were asked to state the percentage of the income they get from different sources, and the average amount of money the sample gets from allowance is $56.62 \%$, earned from the student job $22.75 \%$ and $10.77 \%$ from scholarship.

In terms of the stated acquisition of financial information, the sample is very interested in the matter, $77.64 \%$ of them report they inform themselves about financial issues. Predominantly from the internet $(61.70 \%)$ and from friends $(43.27 \%)$.

\section{Results}

\subsection{Correlations}

Prior to the structural model analysis, we investigate the relationships among the researched constructs and correlations among the constructs are revealed in Table 5. Naturally, three identified elements of materialism are positively related with high statistical significance. Materialism as happiness tracks somewhat higher means than the other two elements of materialism among young adults.

Cognitive impulsiveness is positively related only to materialism as centrality, whereas affective impulsiveness is positively related to all three reported elements, namely, success, centrality and happiness. Cognitive and affective impulsiveness is logically positively related and negatively related to responsible financial behavior; whereas affective impulsiveness tracks a somewhat weaker link. Finally, sex is related to all reported variables except responsible financial behavior, mother education very weakly to cognitive impulsiveness, whereas age is not related to any of the reported constructs. 
Table 3 Overview of sample composition

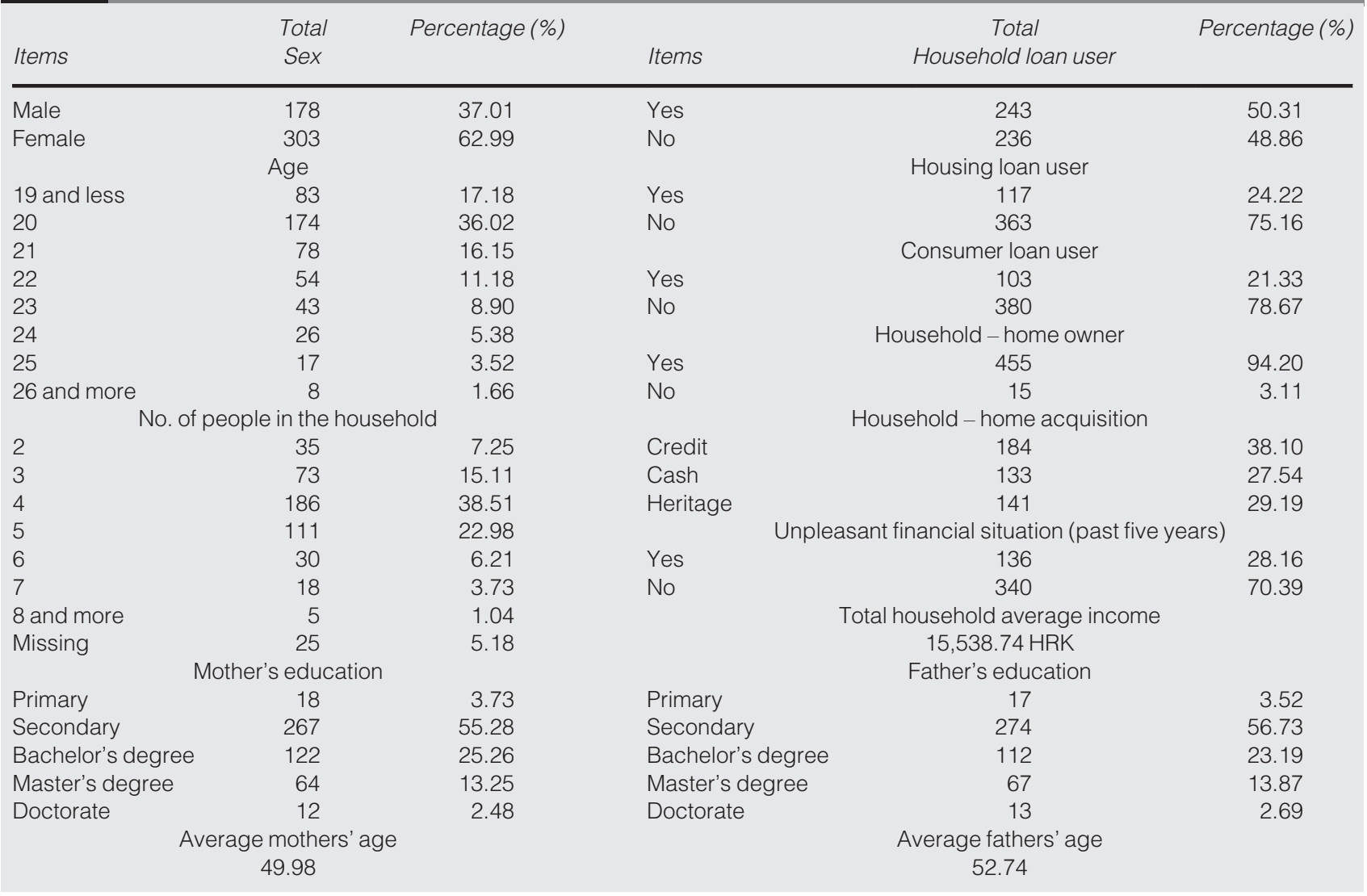

\begin{tabular}{|c|c|c|c|c|c|c|c|c|}
\hline \multirow{2}{*}{$\begin{array}{l}\text { Average (\%) } \\
0\end{array}$} & \multicolumn{2}{|c|}{$\begin{array}{l}\text { Student job } \\
\text { 22.75(\%) }\end{array}$} & \multicolumn{2}{|c|}{$\begin{array}{l}\text { Allowance } \\
56.62(\%)\end{array}$} & \multicolumn{2}{|c|}{$\begin{array}{l}\text { Scholarship } \\
10.77(\%)\end{array}$} & \multicolumn{2}{|c|}{$\begin{array}{l}\text { Other } \\
8.94(\%)\end{array}$} \\
\hline & 250 & 53.19 & 86 & 18.30 & 375 & 79.79 & 379 & 80.64 \\
\hline 10 & 28 & 5.96 & 24 & 5.11 & 5 & 1.06 & 19 & 4.04 \\
\hline 20 & 31 & 6.60 & 20 & 4.26 & 14 & 2.98 & 11 & 2.34 \\
\hline 30 & 26 & 5.53 & 24 & 5.11 & 13 & 2.77 & 7 & 1.49 \\
\hline 40 & 14 & 2.98 & 10 & 2.13 & 4 & 0.85 & 4 & 0.85 \\
\hline 50 & 46 & 9.79 & 60 & 12.77 & 19 & 4.04 & 8 & 1.70 \\
\hline 60 & 9 & 1.91 & 16 & 3.40 & 6 & 1.28 & 0 & 0.00 \\
\hline 70 & 22 & 4.68 & 23 & 4.89 & 4 & 0.85 & 2 & 0.43 \\
\hline 80 & 8 & 1.70 & 34 & 7.23 & 6 & 1.28 & 5 & 1.06 \\
\hline 90 & 13 & 2.77 & 29 & 6.17 & 4 & 0.85 & 4 & 0.85 \\
\hline 100 & 23 & 4.89 & 133 & 28.30 & 15 & 3.19 & 20 & 4.26 \\
\hline Total & 470 & & 459 & & 465 & & 459 & \\
\hline
\end{tabular}

\subsection{Descriptive and the partial least squares-structural equation modeling model reliability and validity analysis}

The proposed structural model was calculated within the partial least squares-structural equation modeling (PLS-SEM) program to test the influence of three different elements of materialistic values on the cognitive and affective impulsiveness, as well as the influence of the two on responsible financial behavior. PLS-SEM is considered adequate for such models (Hair et al., 2011). 
Table 5 Correlations

\begin{tabular}{|c|c|c|c|c|c|c|c|c|c|c|c|}
\hline Variables & Mean & Std. dev. & Success & Materialis & orrelations & Cognitive & Affective & $R C B$ & Sex & Age & $\begin{array}{l}\text { Mother's } \\
\text { education }\end{array}$ \\
\hline Materialism success & 3.5952 & 1.303 & 1 & $0.399 * *$ & $0.532 * *$ & -0.013 & $0.266^{* *}$ & 0.042 & $-0.169^{* *}$ & -0.053 & 0.031 \\
\hline Materialism centrality & 3.5804 & 1.250 & & 1 & $0.266^{* *}$ & $0.346^{* *}$ & $0.523^{* *}$ & $-0.160^{* *}$ & $0.107^{*}$ & -0.074 & 0.076 \\
\hline Materialism happiness & 3.6506 & 1.376 & & & 1 & -0.051 & $0.247^{* *}$ & 0.045 & $-0.145^{* *}$ & -0.032 & -0.054 \\
\hline Cognitive impulsiveness & 3.3660 & 1.176 & & & & 1 & $0.402^{* *}$ & $-0.449^{* *}$ & $0.169^{* *}$ & -0.037 & $0.098^{*}$ \\
\hline Affective impulsiveness & 3.5497 & 1.192 & & & & & 1 & $-0.144^{* *}$ & $0.212^{* *}$ & -0.042 & 0.052 \\
\hline $\mathrm{RCB}$ & 5.3071 & 0.993 & & & & & & 1 & -0.046 & -0.051 & -0.071 \\
\hline Sex & 1.6299 & 0.483 & & & & & & & 1 & 0.072 & $-0.100^{*}$ \\
\hline Age & 20.9751 & 1.784 & & & & & & & & 1 & $-0.102^{*}$ \\
\hline Mother's education & 2.5528 & 0.858 & & & & & & & & & 1 \\
\hline
\end{tabular}

The model comprises six first-order constructs; five out of six variables are reflexive variables, namely, materialism as a success, materialism as acquisition centrality, materialism as happiness, cognitive impulsiveness and affective impulsiveness. The only formative variable in the model is responsible financial behavior that was modeled as such by the authors of the scale (Barbić et al., 2019). Three variables entered the model as control ones and were measured with a single item commonly used in PLS-SEM modeling (Henseler et al., 2009). As for the sample size, it is confirmed that the sample size of 483 to be more than adequate relative to the number of relations tested in the model (Hair et al., 2010, p. 102).

Before further hypotheses testing, it is essential to analyze the reliability and validity of the inner and outer parts of the structural model. Reflexive variables reliability and validity are confirmed through the estimation of composite reliability of indicators, analysis of average variance extracted (AVE), discriminant validity and for formative with homological validity, the significance of weights and testing multicollinearity (Henseler et al., 2009).

Table 6 reveals that all variables in the model have factor loadings larger than 0.65 (Hair et al., 2014, p. 103) as AVE and composite reliability was larges in this range. To come to that, there was a total of two items for affective impulsiveness, five for cognitive impulsiveness, four for materialism as centrality, three for materialism as success and two for materialism as happiness rejected from the model because their loading was less than that. However, that did not intervene with all other indices representing variable reliability and model fit. All average variances extracted are larger than 0.5 (Hair et al., 2014), and all levels of composite reliability and Cronbach's alpha are larger than 0.7 (Henseler et al., 2009), all of which indicate that variables in the model are valid and reliable.

The discriminant validity of constructs is proven in Table 7 using the Fornell and Larcker (1981) criterion.

The only formative variable, responsible financial behaviour (RFB), as error-free as elaborated in the theoretical framework, is reliable as all six factors of it are ensured with statistical significance $p<0.000$.

Moreover, all the indicators in this model have variance Inflation factor lower than 2 ensuring the absence of multicollinearity (Hair et al., 2014, p. 430). Also, the model fit is rated by $R^{2}$; for affective impulsiveness is 0.302 , for cognitive impulsiveness 0.161 and for responsible financial behavior 0.278 , directing toward strong, weak and medium strength of determination (Chin, 1998, p. 323). Indicating the strengths of the influence, the Cohen coefficient $f^{2}$ designates that three variables have very strong influence on exogenous variables; materialism as centrality on affective impulsiveness (0.285) and on cognitive impulsiveness (0.185) and cognitive impulsiveness on responsible financial behavior 
Item

indicator Items

Loadings AVE

Cronbach's

alpha

Affective impulsiveness

$0.5100 .892 \quad 0.862$

AffIMPLS1 It is a struggle to leave nice things I see in a shop

0.715

AffIMPLS10 I sometimes buy things because I like buying things, rather than because I need

0.726 them

AffIMPLS2 I sometimes cannot suppress the feeling of wanting to buy something $\quad 0.758$

AffIMPLS5 I can become very excited if I see something, I would like to buy 0.658

AffIMPLS6 I always see something nice whenever I pass by shops $\quad 0.659$

AffIMPLS7 I find it difficult to pass up a bargain

AffIMPLS8 If I see something new, I want to buy it

0.650

AffIMPLS9 I am a bit reckless in buying things

0.817

Cognitive impulsiveness

0.739

CogIMPLS10l often buy things without thinking

CogIMPLS2 I usually only buy things that I intend to buy*

0.635

CogIMPLS4 Most of my purchases are planned in advance*

0.759

0.765

CogIMPLS5 I only buy things that I really need*

0.821

CogIMPLS8 Before I buy something, I always carefully consider whether I need it*

0.785

Materialism centrality

$\begin{array}{lll}\text { Mat10 I enjoy spending money on things that are not practical } & 0.791\end{array}$

$\begin{array}{lll}\text { Mat11 } & \text { Buying things gives me a lot of pleasure } & 0.851\end{array}$

$\begin{array}{ll}\text { Mat12 I like a lot of luxury in my life } & 0.787\end{array}$

Materialism happiness

Mat15 My life would be better if I owned certain things I do not have $\quad 0.836$

$\begin{array}{lll}\text { Mat17 I would be happier if I could afford to buy more things } & 0.858\end{array}$

Mat18 It sometimes bothers me quite a bit that I cannot afford to buy all the things I would $\quad 0.872$

\section{Materialism success} like

Mat2

Some of the most important achievements in life include acquiring material possessions

Mat4 The things I own say a lot about how well I am doing in life

0.7320 .891

0.820

Mat5 I like to own things that impress people

I admire people who own expensive homes, cars and clothes

0.801

0.6020 .858

0.796

0.737

0.772

0.792

Note: *Presents reverse scoring

\section{Table 7 Discriminant validity of reflexive variables in the model}

\begin{tabular}{|c|c|c|c|c|c|}
\hline Variables & $\begin{array}{c}\text { Affective } \\
\text { impulsiveness }\end{array}$ & $\begin{array}{c}\text { Cognitive } \\
\text { impulsiveness }\end{array}$ & $\begin{array}{c}\text { Materialism } \\
\text { centrality }\end{array}$ & $\begin{array}{c}\text { Materialism } \\
\text { happiness }\end{array}$ & $\begin{array}{l}\text { Materialism } \\
\text { success }\end{array}$ \\
\hline $\begin{array}{l}\text { Affective impulsiveness } \\
\text { Cognitive }\end{array}$ & 0.714 & & & & \\
\hline impulsiveness & 0.418 & 0.756 & & & \\
\hline Materialism centrality & 0.533 & 0.348 & 0.810 & & \\
\hline Materialism happiness & 0.276 & -0.075 & 0.282 & 0.856 & \\
\hline Materialism success & 0.280 & -0.012 & 0.388 & 0.512 & 0.776 \\
\hline
\end{tabular}

(0.228). All other endogenous variables have a weak influence on designated exogenous variables.

Besides, the Stone-Geisser test (Henseler et al., 2009) direct toward medium to weak relevancy of prediction (affective impulsiveness 0.141; cognitive impulsiveness 0.083; responsible financial behavior 0.089 ).

The addition of the three control variables in the model did not change any of the hypothesis relations, therefore not influencing the decisions of in the model. Also, none of the tested relationships were statistically significant. 


\subsection{Hypotheses testing}

The results of the model are available in Figure 2 and Tables 8-10.

It is important to note that neither of the three elements of materialism has no significant direct effect on responsible financial behavior, which can be seen in Table 8. Table 9 revealing the data uncovers that there are no significant indirect effects of materialism on the RFB through affective impulsiveness, hence $\mathrm{H} 2$ is not confirmed. Materialism through neither of the three elements has no statistically significant contribution neither direct nor through the affective impulsiveness on the responsible financial behavior.

At the same time, the data reveals that there is statistically significant full mediation of cognitive impulsiveness in the relationship of all three elements of materialism, centrality, success and happiness and responsible financial behavior, confirming the H1. More specifically, cognitive impulsiveness underlies the relationship between materialism and responsible financial behavior. Cognitive impulsiveness carries the effect of materialism as

\section{Figure 2 Results of the PLS-SEM structural equation model}

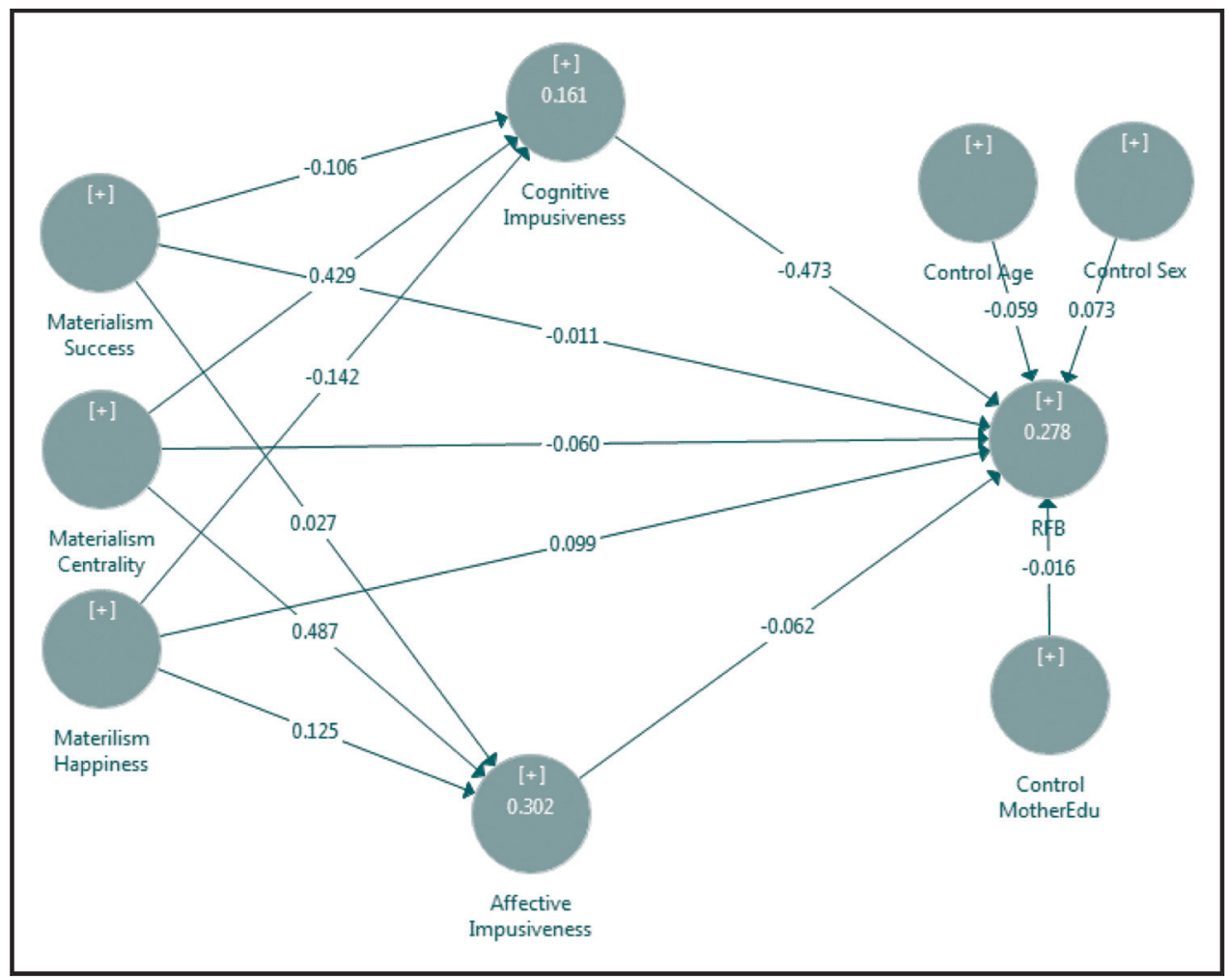

\section{Table 8 Direct effects for mediation}

Direction

Affective impulsiveness $\rightarrow$ RFB

Cognitive impulsiveness $\rightarrow$ RFB

Materialism centrality $\rightarrow$ RFB

Materialism success $\rightarrow$ RFB

Materialism happiness $\rightarrow$ RFB
Original sample (O) Sample mean (M) Standard deviation (STDEV) T-statistics (|O/STDEV) P-values

$\begin{array}{rr}-0.062 & -0.066 \\ -0.473 & -0.477 \\ -0.060 & -0.058 \\ -0.011 & -0.007 \\ 0.099 & 0.096\end{array}$

0.066
0.052
0.055
0.059
0.066

0.933

9.133

1.092

0.183

1.498

0.351

0.000

0.275

0.855

0.135 
Table 9 Indirect effects for mediation

\begin{tabular}{|c|c|c|c|c|c|}
\hline Direction & $\begin{array}{l}\text { Original sample } \\
\text { (O) }\end{array}$ & $\begin{array}{l}\text { Sample mean } \\
\text { (M) }\end{array}$ & $\begin{array}{l}\text { Standard deviation } \\
\text { (STDEV) }\end{array}$ & $\begin{array}{c}\text { T-statistics }(\mid O / \\
\text { STDEV) }\end{array}$ & $\begin{array}{c}\mathrm{P}- \\
\text { values }\end{array}$ \\
\hline $\begin{array}{l}\text { Materialism centrality } \rightarrow \text { affective impulsiveness } \\
\rightarrow \text { RFB }\end{array}$ & -0.030 & -0.032 & 0.032 & 0.932 & 0.352 \\
\hline $\begin{array}{l}\text { Materialism success } \rightarrow \text { affective impulsiveness } \rightarrow \\
\text { RFB }\end{array}$ & -0.002 & -0.002 & 0.005 & 0.316 & 0.752 \\
\hline $\begin{array}{l}\text { Materialism happiness } \rightarrow \text { affective impulsiveness } \\
\rightarrow \text { RFB }\end{array}$ & -0.008 & -0.008 & 0.009 & 0.851 & 0.395 \\
\hline $\begin{array}{l}\text { Materialism centrality } \rightarrow \text { cognitive impulsiveness } \\
\rightarrow \text { RFB }\end{array}$ & -0.203 & -0.207 & 0.032 & 6.343 & 0.000 \\
\hline $\begin{array}{l}\text { Materialism success } \rightarrow \text { cognitive impulsiveness } \rightarrow \\
\text { RFB }\end{array}$ & 0.050 & 0.052 & 0.026 & 1.925 & 0.055 \\
\hline $\begin{array}{l}\text { Materialism happiness } \rightarrow \text { cognitive impulsiveness } \\
\rightarrow \text { RFB }\end{array}$ & 0.067 & 0.069 & 0.026 & 2.568 & 0.011 \\
\hline
\end{tabular}

centrality on irresponsible financial behavior. Both materialism as success and materialism as happiness turn out to have very mild, but still positive net indirect effect to the responsible financial behavior against our expectation, but with relatively small statistical significance $(p=0.055, p=0.011)$.

Hypothesis testing for $\mathrm{H} 3$ and $\mathrm{H} 4$ reveals somewhat interesting results available in Table 10. In terms of the influence of materialism on cognitive impulsiveness, only materialism as centrality proves to have a statistically significant $(p=0.000)$ and very large positive effect, therefore accepting $\mathrm{H} 3 \mathrm{~b}$. Materialism as happiness and as success do not have a statistically significant contribution to cognitive impulsiveness.

In terms of affective impulsiveness, again we found only materialism as centrality to have a statistically significant $(p=0.000)$ and very large positive effect, accepting $H 4 b$. Furthermore, we did not find any significant effect of materialism as a success. Finally, with a $p$-value of 0.013 , considering if the $p$-value is less than 0.05 , it can be concluded that there is a significant difference and by lowering the level of statistical error, we found that materialism as happiness has a positive effect on affective impulsiveness.

Table 10 Hypotheses testing for $\mathrm{H} 3$ and $\mathrm{H} 4$

\begin{tabular}{|c|c|c|c|c|c|c|}
\hline \multicolumn{2}{|c|}{ Hypothesis Direction } & $\begin{array}{c}\text { Original } \\
\text { sample }(O)\end{array}$ & $\begin{array}{l}\text { Sample } \\
\text { mean (M) }\end{array}$ & $\begin{array}{c}\text { Standard deviation } \\
\text { (STDEV) }\end{array}$ & $\begin{array}{l}\text { T-statistics }(\mid O / \\
\text { STDEV) }\end{array}$ & $\begin{array}{c}\mathrm{P}- \\
\text { values }\end{array}$ \\
\hline \multicolumn{7}{|l|}{ H3 } \\
\hline H3a & $\begin{array}{l}\text { Materialism happiness } \rightarrow \text { cognitive } \\
\text { impulsiveness }\end{array}$ & -0.130 & -0.126 & 0.058 & 2.228 & 0.026 \\
\hline H3b & $\begin{array}{l}\text { Materialism centrality } \rightarrow \text { cognitive } \\
\text { impulsiveness }\end{array}$ & 0.428 & 0.431 & 0.046 & 9.381 & 0.000 \\
\hline H3C & $\begin{array}{l}\text { Materialism success } \rightarrow \text { cognitive } \\
\text { impulsiveness }\end{array}$ & -0.110 & -0.114 & 0.056 & 1.953 & 0.051 \\
\hline \multicolumn{7}{|l|}{$\mathrm{H} 4$} \\
\hline $\mathrm{H} 4 \mathrm{a}$ & $\begin{array}{l}\text { Materialism happiness } \rightarrow \text { affective } \\
\text { impulsiveness }\end{array}$ & 0.121 & 0.126 & 0.049 & 2.489 & 0.013 \\
\hline$H 4 b$ & $\begin{array}{l}\text { Materialism centrality } \rightarrow \text { affective } \\
\text { impulsiveness }\end{array}$ & 0.489 & 0.488 & 0.038 & 12.793 & 0.000 \\
\hline $\mathrm{H} 4 \mathrm{C}$ & $\begin{array}{l}\text { Materialism success } \rightarrow \text { affective } \\
\text { impulsiveness }\end{array}$ & 0.027 & 0.033 & 0.053 & 0.515 & 0.607 \\
\hline
\end{tabular}




\section{Discussion and conclusion}

According to the presented results, conducted research established that cognitive impulsiveness fully mediates the relationship between materialism (as centrality, success and happiness) and RFB, at the same time it is important to note that materialism has no direct effect on RFB. Such findings confirm that those who are prone to materialism have lower control over their consumption (Lee and Ahn, 2016), they are prone to make ineffective financial decisions and vulnerable to irresponsible financial behavior (Barbić et al., 2019). Consequently, lack of self-control, lack of planning and absence of consideration of long-term consequence of purchasing refers to cognitive impulsiveness (de Meza et al., 2008; Rook and Fisher, 1995) and lead to irresponsible decision, irresponsible financial behavior and inefficient financial decision (Jelihovschi et al., 2018) as well. At the same time, responsible financial behavior implies rational decisions, planning and self-control during the purchase (Barbić et al., 2019). Therefore, it should be concluded that materialism drives cognitive impulsiveness, which leads to irresponsible financial behavior, which could have negative effects on young consumers' financial stability in the future.

In previously published research, there was no relation between materialism and responsible or irresponsible financial behavior, especially in terms of debt accumulation (Watson, 2003; Norvilitis et al., 2006; Pinto et al., 2000). Nevertheless, there should be a positive effect of self-discipline and thoroughness as personal traits on responsible financial behavior (Tang et al., 2015) and, accordingly, in the absence of these traits, there should be a negative effect of affective impulsiveness on responsible financial behavior. However, according to our research, there are no significant effects of materialism on responsible financial behavior among young consumers found through the mediation of affective impulsiveness.

Furthermore, our research found a strong and statistically significant positive influence of materialism on cognitive impulsiveness only as centrality. Centrality positively affects cognitive impulsiveness through public opinion and self-consciousness that shape purchase decisions and provoke the acquisition of goods (Richins, 1994; Xu, 2008). On the other hand, the research concluded materialism as happiness and success do not have a statistically significant effect on cognitive impulsiveness. Stated is not accordant to previous research studies where success and happiness, as values of materialism, motivate a person to make financial decisions, purchase decisions and financial goals to find happiness and achieve personal success (Chen, 2016; Cakarnis and D'Alessandro, 2015; Stone et al., 2008), and hence, make positive influence on impulsiveness. Consequently, it could be concluded that the significant influence of materialism on cognitive impulsiveness among young consumers is achieved only through public opinion and self-consciousness that influence on their focus, consideration and planning during the purchase.

Considering affective impulsiveness, materialism has a strong and statistically significant positive influence only as centrality. Positive influence of materialism as centrality was identified through emotions and personality traits that a person wants to experience and gain by making a purchase (Chatterjee and Farkas, 1992; Dittmar, 2000). Furthermore, happiness has a weaker but positive influence on affective impulsiveness, which is partly accordant to previous research studies where happiness, as the value of materialism, has a negative influence on a person's quality of life (Sirgy, 1998) but has a positive influence on affective impulsiveness through the person's tendency to achieve happiness through the purchase (Tang et al., 2014). Finally, our research found there is no statistically significant effect of materialism as success on affective impulsiveness, which is not accordant to previous research studies where the positive influence of success is visible from the desire for improvement of social status by purchasing (Kasser et al., 1995). It can be concluded influence of materialism on affective impulsiveness is visible through young consumers' emotions, personality traits and happiness they want to achieve through the purchase. 
We conducted this study to uncover the mechanism behind the materialism as an antecedent factor of impulsiveness and its effect on the responsible financial behavior among young adults. The conclusions lead to the point that even though materialism has no direct effect on responsible financial behavior, the relationship between them is fully mediated by cognitive impulsiveness. Hence, those that are prone to materialism are more likely to make purchase decisions under cognitive impulsiveness that will contribute to irresponsible financial behavior. Therefore, by increasing money management skills, there would be a positive effect on the decrease of impulsive purchases, by evoking the benefits of deliberation of the purchase on their future well-being. Moreover, as only materialism as centrality was found to have a strong positive influence on cognitive and affective impulsiveness, young adults' materialism desire to control their own existence through acquisition drives their impulsiveness and irresponsible financial decision-making.

Presented findings of the influence of materialism on impulsiveness and effects of these variables on responsible financial behavior are crucial for both researchers' and public policymakers' better understanding and predicting of financial behavior among young adults. The implications highlight that the regulatory bodies and financial service providers have a possibility to play a significant role in reducing irresponsible financial behavior among young adults. By being transparent and providing both formal and informal education aimed at forming less materialistic value foundations and negative attitudes toward borrowing, institutions can suppress impatient financial decisions and protect young consumers. That could be done through social marketing campaigns or through the targeted communication with young clients. We suggest that as a matter of policy, young adults should be provided with voluntary learning programs provided by financial institutions. Furthermore, the programs should be promoted through sets of messages aiming at self-consciousness and addressing desirable attitudes toward consumption and materialistic possession. Also, the results of this study imply that it is as well important to act upon decreasing people's materialism to influence their rational purchase decisions. That could be done through a wide variety of policies and interventions that diminish the focus on consumption as a foundation of economic growth.

The main limitation of this study is its sample structure that was positively biased; including only business students that are more informed of the topic. Therefore, future research could expand the sample and include students in other fields of studies, as well as young adults who are working full-time. This study is conducted only on Croatian consumers, therefore future studies should extend the investigation on other territories. Moreover, future studies should include the investigation of the efficiency of financial education (both formal and informal) on the researched mechanism. Also, future studies should address how this mechanism functions within the clusters of consumers relative to their specific personality traits or even different life-cycle stage. To enlarge the relevance of these conclusions, future research should address the influence of a diverse set of financial socialization agents on the addressed influence of materialism on the impulsiveness and responsible financial behavior of young adults.

\section{References}

Ahuvia, A.C. and Wong, N.Y. (2002), "Personality and values based materialism: their relationship and origins", Journal of Consumer Psychology, Vol. 12 No. 4, pp. 389-402.

Arndt, J., Solomon, S., Kasser, T. and Sheldon, K.M. (2004), "The urge to splurge: a terror management account of materialism and consumer behavior", Journal of Consumer Psychology, Vol. 14 No. 3, pp. 198-212.

Bamforth, J., Jebarajakirthy, C. and Geursen, G. (2018), 'Understanding undergraduates' money management behaviour: a study beyond financial literacy", International Journal of Bank Marketing, Vol. 36 No. 7 , pp. 1285-1310.

Bapat, D. (2020), "Antecedents to responsible financial management behavior among young adults: moderating role of financial risk tolerance", International Journal of Bank Marketing, Vol. 38 No. 5, pp. 1177-1194. 
Barbić, D., Lučić, A. and Chen, J.M. (2019), "Measuring responsible financial consumption behavior", International Journal of Consumer Studies, Vol. 43 No. 1, pp. 102-112.

Belk, R.W. (1984), "Three scales to measure constructs related to materialism: reliability, validity, and relationships to measures of happiness", in Thomas C.K., (Ed.), NA - Advances in Consumer Research, Vol. 11, Association for Consumer Research, Provo, UT, pp. 291-297.

Bernthal, M.J., Crockett, D. and Rose, R.L. (2005), "Credit cards as lifestyle facilitators", Journal of Consumer Research, Vol. 32 No. 1, pp. 130-145.

Burroughs, J.E. and Rindfleisch, A. (2002), "Materialism and well-being: a conflicting values perspective", Journal of Consumer Research, Vol. 29 No. 3, pp. 348-370.

Cakarnis, J. and D'Alessandro, S.P. (2015), "Does knowing overcome wanting? The impact of consumer knowledge and materialism upon credit card selection with young consumers", Young Consumers, Vol. 16 No. 1, pp. 50-70.

Chatterjee, P. and Farkas, K.J. (1992), "Spending behaviors: implications for human service practitioners", Families in Society: The Journal of Contemporary Social Services, Vol. 73 No. 10, pp. 613-622.

Chen, J.M. (2016), Finance and the Behavioral Prospect: Risk, Exuberance, and Abnormal Markets, Palgrave Macmillan, New York, NY.

Chin, W.W. (1998), "The partial least squares approach to structural equation modeling", Modern Methods for Business Research, Vol. 295 No. 2, pp. 295-336.

Christopher, A.N., Marek, P. and Carroll, S.M. (2004), "Materialism and attitudes toward money: an exploratory investigation", Individual Differences Research, Vol. 2 No. 2, pp. 109-117.

Csikszentmihalyi, M. and Rochberg-Halton, E. (1981), The Meaning of Things: domestic Symbols and the Self, Cambridge University Press, Cambridge.

de Matos, C.A., Vieira, V., Bonfanti, K. and Mette, F.M.B. (2019), "Antecedents of indebtedness for low-income consumers: the mediating role of materialism", Journal of Consumer Marketing, Vol. 36 No. 1, pp. 92-101.

de Meza, D., Irlenbusch, B. and Reyniers, D. (2008), "Financial capability: a behavioural economics perspective", Consumer Research, Vol. 69, pp. 192-193.

Demirbag, M., Sahadev, S. and Mellahi, K. (2010), "Country image and consumer preference for emerging economy products: the moderating role of consumer materialism", International Marketing Review, Vol. 27 No. 2, pp. 141-163.

Diener, E.D., Emmons, R.A., Larsen, R.J. and Griffin, S. (1985), "The satisfaction with life scale”, Journal of Personality Assessment, Vol. 49 No. 1, pp. 71-75.

Dittmar, H. (2000), "The role of self-image in excessive buying", in Benson, A. (Ed.), I Shop, Therefore I Am: Compulsive Buying and the Search for Self, Aronson, New York, NY, pp. 105-132.

Dittmar, H. and Bond, R. (2010), "I want it and I want it now: using a temporal discounting paradigm to examine predictors of consumer impulsivity", British Journal of Psychology, Vol. 101 No. 4, pp. 751-776.

Eastman, J., Goldsmith, R. and Flynn, L. (1999), "Status consumption in consumer behavior: scale development and validation", Journal of Marketing Theory and Practice, Vol. 7 No. 3, pp. 41-52.

Fornell, C. and Larcker, D.F. (1981), "Structural equation models with unobservable variables and measurement error: algebra and statistics", Journal of Marketing Research, Vol. 18 No. 3, pp. 382-388.

Garðarsdottir, R.B. and Dittmar, H. (2012), "The relationship of materialism to debt and financial well- being: the case of Iceland's perceived prosperity", Journal of Economic Psychology, Vol. 33 No. 3, pp. 471-481.

Hair, J.F., Ringle, C.M. and Sarstedt, M. (2011), "PLS-SEM: indeed a silver bullet", Journal of Marketing Theory and Practice, Vol. 19 No. 2, pp. 139-152.

Hair, J.F., Jr, Anderson, R.E., Babin, B.J. and Black, W.C. (2010), Multivariate Data Analysis: A Global Perspective, Pearson Education, Upper Saddle River, New York, NY.

Hair, J.F., Jr, Sarstedt, M., Hopkins, L. and Kuppelwieser, V.G. (2014), "Partial least squares structural equation modeling (PLS-SEM): an emerging tool in business research", European Business Review, Vol. 26 No. 2, pp. 106-121.

Hauss, J.C., Garling, T. and Lindbolm, T. (2019), Indebtedness in Early Adulthood Causes and Remedies: Causes and Remedies, Palgrave Macmillan. 
Helm, S., Serido, J., Ahn, S.Y., Ligon, V. and Shim, S. (2019), "Materialist values, financial and proenvironmental behaviors, and well-being", Young Consumers, Vol. 20 No. 4, pp. 264-284.

Henseler, J., Ringle, C.M. and Sinkovics, R.R. (2009), "The use of partial least squares path modeling in international marketing", in Sinkovics, R.R. and Ghauri, P.N. (Eds), New Challenges to International Marketing (Advances in International Marketing, Vol. 20, Emerald Group Publishing, Bingley, pp. 277-319.

Jelihovschi, A.P., Cardoso, R.L. and Linhares, A. (2018), "An analysis of the associations among cognitive impulsiveness, reasoning process, and rational decision making", Frontiers in Psychology, Vol. 8, pp. 1-10.

Johnson, E. and Sherraden, M.S. (2007), "From financial literacy to financial capability among youth", Journal of Sociology and Social Welfare, Vol. 34 No. 3, pp. 119-146.

Kasser, T., Cohn, S., Kanner, A.D. and Ryan, R.M. (2007), "Some costs of American corporate capitalism: a psychological exploration of value and goal conflicts", Psychological Inquiry, Vol. 18 No. 1, pp. 1-22.

Kasser, T., Ryan, R.M., Zax, M. and Sameroff, A.J. (1995), "The relations of maternal and social environments to late adolescents' materialistic and prosocial values", Developmental Psychology, Vol. 31 No. 6, pp. 907-914.

Lee, M.S. and Ahn, C.S.Y. (2016), "Anti-consumption, materialism, and consumer well-being", Journal of Consumer Affairs, Vol. 50 No. 1, pp. 18-47.

Lysonski, S. and Durvasula, S. (2013), "Consumer decision making styles in retailing: evolution of mindsets and psychological impacts", Journal of Consumer Marketing, Vol. 30 No. 1, pp. 75-87.

McKelvie, S.J. (1978), "Graphic rating scales — how many categories?", British Journal of Psychology, Vol. 69 No. 2, pp. 185-202.

McNair, S., Summers, B., de Bruin, W. and Ranyard, R. (2016), "Individual-level factors predicting consumer financial behavior at a time of high pressure", Personality and Individual Differences, Vol. 99, pp. 211-216.

Maslow, A. (1954), Motivation and Personality, Harper and Brothers, New York, NY.

Nga, K.J., Yong, H.L. and Sellappan, R. (2011), "The influence of image consciousness, materialism and compulsive spending on credit card usage intentions among youth", Young Consumers, Vol. 12 No. 3 , pp. 243-253.

Norvilitis, J.M., Merwin, M.M., Osberg, T.M., Roehling, P.V., Young, P. and Kamas, M.M. (2006), "Personality factors, money attitudes, financial knowledge, and credit-card debt in college students", Journal of Applied Social Psychology, Vol. 36 No. 6, pp. 1395-1413.

Pandelaere, M. (2016), "Materialism and well-being: the role of consumption", Current Opinion in Psychology, Vol. 10, pp. 33-38.

Phau, I. and Woo, C. (2008), "Understanding compulsive buying tendencies among young Australians: the roles of money attitude and credit card usage", Marketing Intelligence \& Planning, Vol. 26 No. 5, pp. 441-458.

Pinto, M.B., Parente, D.H. and Palmer, T.S. (2000), "Materialism and credit card use by college students", Psychological Reports, Vol. 86 No. 2, pp. 643-652.

Podoshen, J. and Andrzejewski, S. (2012), "An examination of the relationships between materialism, conspicuous consumption, impulse buying, and Brand loyalty", Journal of Marketing Theory and Practice, Vol. 20 No. 3, pp. 319-333.

Richins, M.L. (1994), "Special possessions and the expression of material values", Journal of Consumer Research, Vol. 21 No. 3, pp. 522-533.

Richins, M.L. and Dawson, S. (1992), "A consumer values orientation for materialism and its measurement: scale development and validation", Journal of Consumer Research, Vol. 19 No. 3, pp. 303-316.

Richins, M.L. and Rudmin, F.W. (1994), "Materialism and economic psychology", Journal of Economic Psychology, Vol. 15 No. 2, pp. 217-231.

Robb, C.A. and Sharpe, D.L. (2009), "Effect of personal financial knowledge on college students' credit card behavior", Journal of Financial Counseling and Planning, Vol. 20 No. 1, pp. 25-43.

Roberts, J.A. and Clement, A. (2007), "Materialism and satisfaction with over-all quality of life and eight life domains", Social Indicators Research, Vol. 82 No. 1, pp. 79-92. 
Rokeach, M. (1973), The Nature of Human Values, Free Press, New York, NY.

Rook, D.W. and Fisher, R.J. (1995), "Normative influences on impulsive buying behavior", Journal of Consumer Research, Vol. 22 No. 3, pp. 305-313.

Rucker, D.D. and Galinsky, A.D. (2009), "Conspicuous consumption versus utilitarian ideals: how different levels of power shape consumer behavior", Journal of Experimental Social Psychology, Vol. 45 No. 3, pp. 549-555.

Ryan, L. and Dziurawiec, S. (2001), "Materialism and its relationship to life satisfaction", Social Indicators Research, Vol. 55 No. 2, pp. 185-197.

Sachitra, V., Wijesinghe, D. and Gunasena, W. (2019), "Exploring undergraduates' money-management life: insight from an emerging economy", Young Consumers, Vol. 20 No. 3, pp. 167-189.

Santini, F.D.O., Ladeira, W.J., Vieira, V.A., Araujo, C.F. and Sampaio, C.H. (2019), "Antecedents and consequences of impulse buying: a meta-analytic study", RAUSP Management Journal, Vol. 54 No. 2, pp. $178-204$

Sirgy, M.J. (1998), "Materialism and quality of life", Social Indicators Research, Vol. 43 No. 3, pp. 227-260.

Stone, D.N., Wier, B. and Bryant, S.M. (2008), "Reducing materialism through financial literacy", The CPA Journal, Vol. 78 No. 2, pp. 12-14.

Tang, N., Baker, A. and Peter, P.C. (2015), "Investigating the disconnect between financial knowledge and behavior: the role of parental influence and psychological characteristics in responsible financial behaviors among young adults", Journal of Consumer Affairs, Vol. 49 No. 2, pp. 376-406.

Tang, T.L.P., Luna-Arocas, R., Pardo, I.Q. and Tang, T.L.N. (2014), "Materialism and the bright and dark sides of the financial dream in Spain: the positive role of money attitudes-the Matthew effect", Applied Psychology, Vol. 63 No. 3, pp. 480-508.

Taylor, M. (2011), "Measuring financial capability and its determinants using survey data", Social Indicators Research, Vol. 102 No. 2, pp. 297-314.

Verplanken, B. and Herabadi, A. (2001), "Individual differences in impulse buying tendency: feeling and no thinking", European Journal of Personality, Vol. 15 No. 1_suppl, pp. 71-83.

Watson, J.J. (2003), "The relationship of materialism to spending tendencies, saving, and debt", Journal of Economic Psychology, Vol. 24 No. 6, pp. 723-739.

Watson, D.C. (2015), "Materialism and the Five-Factor model of personality: a facet-level analysis", North American Journal of Psychology, Vol. 17 No. 1, pp. 133-150.

Xiao, J.J. (2008), "Applying behavior theories to financial behavior", in Xiao, J.J. (Ed.), Handbook of Consumer Finance Research, Springer, New York, NY, pp. 69-81.

Xiao, J.J. and Dew, J. (2011), "The financial management behavior scale: development and validation", Journal of Financial Counseling and Planning, Vol. 22 No. 1, pp. 43-59.

Xiao, J.J., Serido, J. and Shim, S. (2011), "Financial education, financial knowledge, and risky credit behavior of college students", in Lamdin, D. (Ed.), Consumer Knowledge and Financial Decisions. International Series on Consumer Science, Springer, New York, NY, pp. 113-128.

$\mathrm{Xu}, \mathrm{Y}$. (2008), "The influence of public self-consciousness and materialism on young consumer's compulsive buying”, Young Consumers, Vol. 9 No. 1, pp. 37-48.

Yang, C., De Wang, Y. and Niu, H.J. (2008), "The effects of idolatry and personality traits on impulse buying: an empirical study”, International Journal of Management, Vol. 25 No. 4, pp. 633-640.

\section{Corresponding author}

Andrea Lučić can be contacted at: andrea.lucic@efzg.hr

For instructions on how to order reprints of this article, please visit our website: www.emeraldgrouppublishing.com/licensing/reprints.htm

Or contact us for further details: permissions@emeraldinsight.com 